\title{
THE DISAPPOINTED EXPECTATIONS TEST AND THE ECONOMIC LOSS DOCTRINE
}

\author{
RALPH C. ANZIVINO*
}

\section{INTRODUCTION}

The economic loss doctrine is a judicially created rule that determines whether contract or tort law applies when a defective product causes damage. The doctrine's starting premise is that contract law governs if the defective product causes economic loss and that tort law governs when the defective product causes property damage. A common refrain is that the doctrine was created to prevent contract law from drowning in a sea of tort. However, as the rule has developed, courts have continued to expand contract coverage at the expense of tort coverage. First, when the defective product damages only itself, the courts conclude that such property damage should be resolved under contract law, not tort law. Next, when the defective product damages the system of which it was a component part, the courts conclude that such property damage should also be resolved under contract law, not tort law. The rule that evolved from this judicial process is the "other property" rule, which is also known as the "other property" exception to the economic loss doctrine. Stated more simply, the "other property" rule provides that when a defective product causes property damage, tort law will only be available when the property damage is "other than" damage to the product or its integrated system.

Recently, another rule has begun to receive judicial acceptance that further expands the coverage of contract law at the expense of tort law. The rule is called the "disappointed expectations" test or the "reasonably foreseeable" rule. It provides that property damage that was reasonably foreseeable at the time of contracting is recoverable only under contract law, not tort law. The purpose of this Article is to examine the disappointed expectations rule and determine whether it is a positive addition to the legal landscape of the economic loss doctrine.

* Professor of Law, Marquette University Law School. I would like to thank Luke Schneider, J.D. 2009, Marquette University, for his excellent research on this Article. 


\section{THE “OTHER PROPERTY” EXCEPTION TO THE ECONOMIC LOSS DOCTRINE}

The economic loss doctrine provides that when a defective product causes solely economic loss, ${ }^{1}$ the buyer may pursue damages only through contract law. ${ }^{2}$ On the other hand, if the defective product causes personal injury or property damage, the buyer may pursue damages through tort law. ${ }^{3}$ The rules are simple to state but difficult to apply. As developed by the courts, the determination has become even more difficult. Contract law now covers some types of property damage and tort law covers other types of property damage. For example, a product that fails and damages only itself has caused property damage, but not the type of property damage that permits the use of tort theories. ${ }^{4}$ Damage to the product itself is tantamount to loss of product value and is not considered property damage. ${ }^{5}$ In other words, does it really matter whether the product fails to function properly or simply explodes? In either case, if there is no other damage, the loss is of product value and is considered solely an economic loss. ${ }^{6}$

But what if the defective product causes damages beyond itself and damages the system of which it is a part? Here again, the general rule is that when a defective product causes damage to the system of which it is a part, such property damage is not sufficient to permit the injured party to pursue tort theories. ${ }^{7}$ This is known as the integrated system rule. ${ }^{8}$ The integrated system rule stems from the United States Supreme Court's decision in East River Steamship Corp. v. Trans America Delaval Inc. ${ }^{9}$ In East River, turbines were installed as part of a propulsion system for supertankers. ${ }^{10}$ Upon use, the turbines proved defective and damaged the supertanker's propulsion system. ${ }^{11}$ After incurring $\$ 8$ million in damages, ${ }^{12}$ the ship owners sued the shipbuilder on tort theories, arguing that the defective turbines caused "other property"

1. For a discussion of the distinction between economic loss and noneconomic loss, see generally Ralph C. Anzivino, The Economic Loss Doctrine: Distinguishing Economic Loss from Non-Economic Loss, 91 MARQ. L. REV. 1081 (2008).

2. Sunnyslope Grading, Inc. v. Miller, Bradford \& Risberg, Inc., 437 N.W.2d 213, 217-18 (Wis. 1989).

3. RESTATEMENT (THIRD) OF TORTS: PRODS. LIAB. § 1 (1998).

4. Id. $\S 21 \mathrm{cmt}$. d; see E. River S.S. Corp. v. Transamerica Delaval, Inc., 476 U.S. 858, 871 (1986).

5. See Trans States Airlines v. Pratt \& Whitney Canada, Inc., 682 N.E.2d 45, 52 (Ill. 1997).

6. See id.

7. E. River, 476 U.S. at 875-76; Wausau Tile, Inc. v. County Concrete Corp., 593 N.W.2d 445, 452 (Wis. 1999).

8. Wausau Tile, 593 N.W.2d at 452.

9. 476 U.S. 858 .

10. Id. at 859 .

11. Id. at $860-61$.

12. Id. at 861 . 
damage by injuring the propulsion system. ${ }^{13}$ The Court noted that "[i]n the traditional [other] 'property damage' cases, the defective product damages other property."14 But, in this case, the Court held there was no "other property" damage. ${ }^{15}$ Rather, the Court reasoned that the turbines were part of an integrated product and, as such, when the defective turbines damaged the product of which it was a part, there was no "other property" damage. ${ }^{16}$ The Court reasoned that "all but the very simplest of machines have component parts," and, as such, "“[a contrary] holding would require a finding of [other] 'property damage' in virtually every case where a product damages itself. Such a holding would eliminate the distinction between warranty and strict products liability.",17

The impact of the integrated system rule is to expand the domain of contract law by shrinking those cases that qualify as "other property" damage under tort law. Thus, a defective product that causes damage to itself or its integrated system has not caused sufficient property damage to engender tort remedies. Rather, the defective product must cause property damage other than to itself or its integrated system to trigger tort theories. ${ }^{18}$ This is the "other property" rule of the economic loss doctrine. In this Article the use of the term "other property" is intended to mean property damage that is other than damage to the product or its integrated system.

\section{THE DISAPPOINTED EXPECTATIONS RULE AND “OTHER PROPERTY” DAMAGE}

It is well established that when a defective product causes solely economic loss, the aggrieved buyer's claim will be resolved under contract law. ${ }^{19}$ On the other hand, it is equally clear that if the defective product causes personal injury or property damage, the injured party has a tort claim. ${ }^{20}$ The property damage claim, however, has been narrowed by the integrated system rule so that the property damage must be to property "other than" the product or the system of which it is an integral part. ${ }^{21}$ In other words, a tort claim only exists

\footnotetext{
13. See id. at 867 .

14. Id.

15. Id.

16. $I d$.

17. Id. (second alteration added) (quoting N. Power \& Eng'g Corp. v. Caterpillar Tractor Co., 623 P.2d 324, 330 (Alaska 1981)).

18. Saratoga Fishing Co. v. J.M. Martinac \& Co., 520 U.S. 875, 877 (1997).

19. Sunnyslope Grading, Inc. v. Miller, Bradford \& Risberg, Inc., 437 N.W.2d 213, 218 (Wis.

20. RestATEMENT (THIRD) OF TORTS: PRODS. LiAB. § 1 (1998).

21. See supra Part II.
} 1989). 
if the defective product damages "other property." Contract law and tort law agree on this formulation of the meaning of "other property."

The disappointed expectations rule is a further erosion of the general principle that permits tort claims for damage to "other property." 22 The rule provides that "other property" is not damaged when a defective product causes property damage, "but the damage was within the scope of bargaining, or... 'the occurrence of such damage could have been the subject of negotiations." 23 A number of states have adopted the "disappointed expectations" test or "reasonably foreseeable" test. ${ }^{24}$ Also, some academic literature strongly supports the test. ${ }^{25}$

22. See Grams v. Milk Prods., Inc., 699 N.W.2d 167, 175 (Wis. 2005).

23. Id. (quoting Neibarger v. Universal Coops., Inc., 486 N.W.2d 612, 620 (Mich. 1992)).

24. IOWA: Conveyor Co. v. SunSource Tech. Servs., Inc., 398 F. Supp. 2d 992, 1012-13 (N.D. Iowa 2005) (concluding that claims fell within unfulfilled expectations regarding quality of the hydraulic lift); Tomka v. Hoechst Celanese Corp., 528 N.W.2d 103, 107 (Iowa 1995) (Growth hormone did not grow cattle as expected, and only contract damages were available because product did not perform as expected.); Nelson v. Todd's Ltd., 426 N.W.2d 120, 125 (Iowa 1988) (Harm to Nelson's meat because of defective curing agent led to only contract damages because harm was a foreseeable result from a "failure of the product to work properly."). But see Ballard v. Amana Soc'y, Inc., 526 N.W.2d 558, 562 (Iowa 1995) ("Unlike the damages suffered by the plaintiffs in Nelson, we believe the injuries to the Ballards' swine herd support damages in tort. We believe the existence of toxins in the feed corn was a genuine hazard peripheral to the sale and a serious product defect, causing the death of swine and a significant business interruption.") (Note this is the same court in the same year as Tomka.). KANSAS: AgriStor Leasing v. Meuli, 634 F. Supp. 1208, $1217-$ 18 (D. Kan. 1986) ("This is clearly different than the case at hand where the damage resulted simply from the product's failure to live up to expectations."). KENTUCKY: Gooch v. E.I. Du Pont de Nemours \& Co., 40 F. Supp. 2d 863, 876 (W.D. Ky. 1999) (predicting Kentucky would apply a disappointed performance expectations test to the economic loss doctrine when damages were from chemical applied to corn crop). MICHIGAN: Detroit Edison Co. v. NABCO, Inc., 35 F.3d 236, 241 (6th Cir. 1994) ("[T]ort claims for damage to other property are barred by the economic loss doctrine if those losses are direct and consequential losses that were within the contemplation of the parties..." This case involved a faulty pipe exploding at and damaging a power plant.); Theuerkauf v. United Vaccines Div. of Harlan Sprague Dawley, Inc., 821 F. Supp. 1238, 1241-42 (W.D. Mich. 1993) (holding that damages to mink from vaccine were economic losses and paralleling the case with Neibarger); Neibarger, 486 N.W.2d at 621 (Damage to cattle herd due to faulty milking system were economic losses because economic expectations were not met.). MINNESOTA: Veldhuizen v. A.O. Smith Corp., 839 F. Supp. 669, 677 (D. Minn. 1993) (holding that damages to silage and cattle due to faulty silo that failed to work as expected were economic damages not exempted as "other property"); AgriStor Leasing v. Guggisberg, 617 F. Supp. 902, 908 (D. Minn. 1985) (holding that damages to alfalfa feed and cattle due to faulty silo that failed to work as expected were economic damages not exempted as "other property"); Thofson v. Redex Indus., Inc., 433 N.W.2d 901, 904 (Minn. Ct. App. 1988) (holding that damage to grain due to a faulty grain dryer was economic damage that could be contemplated by the parties and did not fall within "other property" exception). NEW JERSEY: In re Merritt Logan, Inc., 901 F.2d 349, 362 (3d Cir. 1990) (applying a foreseeability approach and holding that damages to food stocks due to a faulty refrigerator were economic losses); Int'l Flavors \& Fragrances, Inc. v. McCormick \& Co., 575 F. Supp. 2d 654, 661, 663 (D.N.J. 2008) (applying a foreseeability analysis and holding, where barbecue seasoning was damaged by faulty paprika, this was not "other property" damage). NORTH DAKOTA: Dakota Gasification Co. v. Pascoe Bldg. Sys., 91 F.3d 1094, 1101 (8th Cir. 1996) 
It has also been predicted that a number of states will reject the disappointed expectations test or reasonably foreseeable test. ${ }^{26}$ The leading case on the disappointed expectations rule is the Wisconsin Supreme Court's decision in Grams v. Milk Products, Inc. ${ }^{27}$ In Grams, dairy farmers purchased a milk substitute to feed their newborn calves during the first few weeks of their lives when the calves' immune systems were developing. ${ }^{28}$ After using the product for a short period, the calves did not gain weight and appeared gaunt and hungry. ${ }^{29}$ In addition, the mortality rates for the calves tripled during the use of the milk substitute. ${ }^{30}$ The Gramses believed that the milk substitute actually damaged the calves' immune systems. ${ }^{31}$ The Gramses filed suit against the manufacturer and others on contract and tort theories for the death and damage caused by the defective product to their calves. ${ }^{32}$ The court acknowledged that the integrated system rule would not preclude the

(holding that the collapse of a plant that damaged materials within were economic damages of a foreseeable risk; also predicting that North Dakota state courts will follow the disappointed performance expectations test); Albers v. Deere \& Co., No. 1:08-cv-040, 2008 U.S. Dist. LEXIS 73189, at *27-28 (D.N.D. Sept. 24, 2008) (holding that damage to combine header due to combine fire was economic damages and following Dakota Gasification's prediction). OKLAHOMA: United Golf, LLC v. Westlake Chem. Corp., No. 05-CV-0495-CVE-PJC, 2006 U.S. Dist. LEXIS 57531, at *14-15 (N.D. Okla. Aug. 15, 2006) (citing Okla. Gas \& Elec. Co. v. McGraw-Edison Co., 834 P.2d 980, 982 (Okla. 1992)) (applying a foreseeability approach and predicting that under Oklahoma law, damages to the course and sod would be economic damages). SOUTH CAROLINA: Palmetto Linen Serv., Inc. v. U.N.X., Inc., 205 F.3d 126, 130 (4th Cir. 2000) (predicting that South Carolina would apply a disappointed performance expectations test and holding that damages to linens due to faulty chemical dispensers in washers were foreseeable and within the contemplation of the parties); Myrtle Beach Pipeline Corp. v. Emerson Elec. Co., 843 F. Supp. 1027, 1061 (D.S.C. 1993) (holding that cleanup costs and damages from pipeline component that caused a spill were economic because they were foreseeable and within contemplation of the parties). VIRGINIA: Sensenbrenner v. Rust, Orling \& Neale, Architects, Inc., 374 S.E.2d 55, 58 (Va. 1988) (holding that, where architect drew faulty design for new home and pool, damages were economic due to disappointed economic expectations); Redman v. John D. Brush \& Co., 111 F.3d 1174, 1182-83 (4th Cir. 1997) (applying Sensenbrenner in a similar manner). WISCONSIN: Grams, 699 N.W.2d at 179-80 (applying the disappointed performance expectations test to conclude that damages were economic where calves were damaged due to defective milk replacer).

25. See, e.g., MacKenzie Mayes Walter, Note, The Solution to the Economic Loss Doctrine Confusion: The Disappointed Expectations Test, 95 KY. L.J. 943 (2006).

26. MARYLAND: Pac. Indem. Co. v. Whaley, 572 F. Supp. 2d 626, 631 (D. Md. 2008) (predicting Maryland as not supportive of a foreseeability test while also distinguishing the property damaged in the house because of the defective roof as "other property"). PENNSYLVANIA: 2-J Corp. v. Tice, 126 F.3d 539, 542-44 (3d Cir. 1997) (predicting Pennsylvania as not supportive of a foreseeability test while also distinguishing the property damaged in the warehouse because of its collapse as "other property").

27. 699 N.W.2d 167.

28. Id. at 170 .

29. Id.

30. Id.

31. Id.

32. Id. 
Gramses' tort claims. ${ }^{33}$ The milk substitute was obviously not a component part of a larger system that would preclude a finding of "other property" damage. Rather, the Wisconsin Supreme Court sought to adopt another exception to the "other property" rule because, in the court's opinion, "[t]he 'integrated system' concept does not translate well to all situations involving property damage to which the economic loss doctrine logically applies." ${ }^{34}$ The court held that "if [the] claimed damages are the result of disappointed expectations of a bargained-for product's performance, the economic loss doctrine applies to bar the plaintiff's tort claims." 35 The Grams result meant that there was no tort claim for the Gramses' "other property" damage.

There are two rationales offered to support adoption of the reasonably foreseeable test. First, the reasonably foreseeable test is a logical extension of the integrated system rule. ${ }^{36}$ The United States Supreme Court in East River created the integrated system rule. ${ }^{37}$ In East River, defective turbines were installed in a ship, and they subsequently damaged the ship's propulsion system. $^{38}$ The Supreme Court held that since the turbines were part of an integrated system, damage to the system should be treated as damage to the product. ${ }^{39}$ The Court reasoned that to hold otherwise would completely engulf all contract law within tort law. ${ }^{40}$ The reasoning of the integrated system rule has been accepted by the Restatement (Third) of Torts. ${ }^{41}$ The premise of the rule is simple. It is reasonably foreseeable that a defective component part will likely damage the system of which it is a part, and, as such, such damage should not be considered "other property" damage, but damage within the contemplation of the sales contract. ${ }^{42}$ When a product is purchased, both parties should be considering the possibility that the product may prove defective and protect themselves accordingly. ${ }^{43}$ Obviously, when the product is a component part of a system, damage to the system is an eminently foreseeable event, and, as such, the contract between the parties should address that possibility. ${ }^{44}$ Thus, the integrated system rule is based

\footnotetext{
33. Id. at 175 .

34. Id.

35. Id. at 169 .

36. Id. at 179.

37. See E. River S.S. Corp. v. Transamerica Delaval, Inc., 476 U.S. 858 (1986); supra Part II.

38. E. River, 476 U.S. at 860.

39. Id. at 867.

40. Id.

41. ReSTATEMENT (THIRD) OF TORTS: PRODS. Liab. $\S 21 \mathrm{cmt}$. e (1998).

42. See E. River, 476 U.S. at 867-68.

43. See id.

44. See Grams v. Milk Prods., Inc., 699 N.W.2d 167, 179 (Wis. 2005).
} 
squarely on the foreseeability that a defective component will damage its system. ${ }^{45}$

The disappointed expectations rule is a logical extension of the integrated system rule. It simply extends the damages that are foreseeable beyond the product's integrated system to all those damages that were foreseeable at the time of contracting. It should be noted, however, that the integrated system rule is manageable because the court or parties need to determine only the system and its component parts. Whereas under the disappointed expectations test, all reasonably foreseeable damages within the scope of the bargain are covered, which is an extremely vague rule. ${ }^{46}$

There is a second and perhaps more compelling reason for the rule. Contract law and product liability law serve different purposes. Product liability law governs the relationship between a consumer and a manufacturer where it is generally not possible for the parties to negotiate all the terms of sale. Product liability law, therefore, places a burden on the manufacturer to produce safe products. On the other hand, contract law applies to commercial transactions where the terms and conditions of the sale can be negotiated to each party's satisfaction. Contract law operates on the assumption that commercial parties through the bargaining process can allocate the costs and risks of the product's nonperformance. When a defective product is purchased in a commercial setting and it causes property damage, both tort and contract law are implicated. When the Grams court adopted the disappointed expectations rule, the court clearly indicated that the bargaining rationale should control. ${ }^{47}$ The court reasoned that " $[\mathrm{t}] \mathrm{he}$ 'disappointed expectations' concept is grounded in contract principles of bargaining and risk sharing, not on a redefinition of 'other property.",48 A fair question, however, is whether the focus should be on the potential bargain or the actual bargain struck between the parties. ${ }^{49}$

The disappointed expectations rule as enunciated by the Grams court is essentially a reasonably foreseeable test. ${ }^{50}$ In other words, if the damages suffered by the buyer of the defective product were reasonably foreseeable at the time of contracting, the buyer should have negotiated for such protection in the contract. ${ }^{51}$ The consequence of the buyer having failed to negotiate for

45. See id.

46. See infra Part IV.

47. Grams, 699 N.W.2d at 176.

48. Id.

49. The author believes the bargaining rationale is a valid one, but only when focused on the actual bargain struck between the parties, and not on a hypothetical bargain, as is the focus of the reasonably foreseeable test. The author's next Article will develop this proposal.

50. Grams, 699 N.W.2d at 182 (Abrahamson, C.J., dissenting).

51. Id. at 178 (majority opinion). 
protection from foreseeable "other property" damage is the preclusion of any tort claim. ${ }^{52}$ In applying the reasonably foreseeable test, the court stated that the first inquiry is to determine the buyer's expectations for the product. ${ }^{53}$ That determination requires "an inquiry into the substance and the purpose of the transaction." 54 In Grams, the court concluded that the purchase of the milk substitute was intended to foster the growth and healthy development of the newborn calves. ${ }^{55}$ The next determination is whether the claim is about the buyer's disappointment with the product's performance. ${ }^{56}$ The court found that it would be difficult to find "a better example of disappointed expectations than a product ... expected to nourish animals but leaves them malnourished" and dead. ${ }^{57}$ In the court's opinion, the malnourishment and high mortality of the calves were reasonably foreseeable consequences of the product's failed performance. ${ }^{58}$ Therefore, the Gramses' failure to anticipate and contract for protection against such "other property" damage prevented them from being able to pursue tort remedies. ${ }^{59}$

Finally, the disappointed expectations rule converts "other property" damage, which is usually compensable through tort law, into consequential damages governed by the Uniform Commercial Code (U.C.C.). Consequential damages are defined by the U.C.C. as "any loss resulting from general or particular requirements and needs of which the seller at the time of contracting had reason to know,"60 and "injury to person or property proximately resulting from any breach of warranty." consequential damages is whether they were reasonably foreseeable by the seller. $^{62}$ It is not necessary that they were actually foreseen. ${ }^{63}$ The U.C.C. imposes an objective rather than a subjective standard in determining whether the seller should have foreseen the consequential damage caused by the seller's breach. ${ }^{64}$

The leading case that illustrates the conversion of "other property" damages into consequential damages is Neibarger v. Universal Cooperatives,

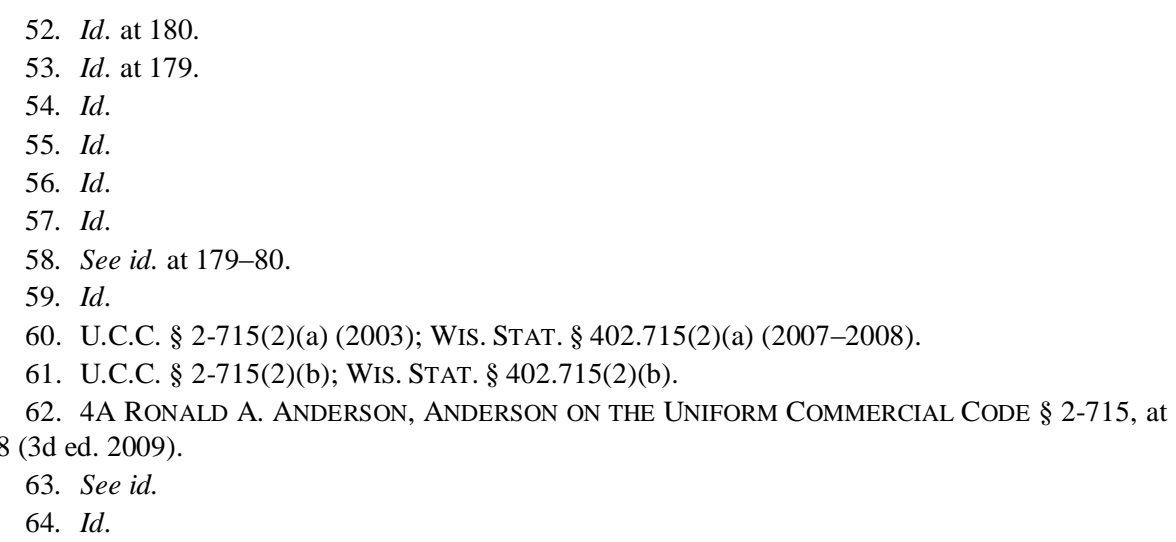


Inc. ${ }^{65}$ In Neibarger, dairy farmers purchased a milking machine to assist in their milking process. ${ }^{66}$ Several years after the milking machine had been in operation, the farmers' cattle became ill and died or had to be sold for slaughter. ${ }^{67}$ The court found that damage caused by the failure of the product to perform as expected caused damage to "other property."68 The court further reasoned that where such "other property" damage was foreseeable at the time of contracting, the U.C.C. provides remedies sufficient to compensate the buyer of a defective product for direct, incidental, and consequential damages, including property damages. ${ }^{69}$

In sum, the disappointed expectations test is a reasonably foreseeable test. One of the rationales for its adoption is that the test is a logical extension of the integrated system rule, which is also a foreseeability rule. However, the integrated system rule is a much more manageable rule than the disappointed expectations rule. Also, the bargaining rationale falls short as a sufficient justification to increase contract coverage at the expense of tort coverage because it focuses on a bargain that could have been struck between the parties rather than on an actual bargain struck between them. Finally, the effect of the disappointed expectations rule is to convert "other property" damage, normally compensable through tort law, into consequential damages under the U.C.C., which thereby subjects the damages to exclusion under the Code.

\section{The CASE Against the Dis APPOINTED EXPECTATIONS TeST}

\section{A. The Disappointed Expectations Rule Grants to Seller/Manufacturer an Un-bargained for and Unspecified Tort Immunity for Its Defective Products}

One of the primary reasons for the creation of the economic loss doctrine was to prevent an aggrieved party, who had suffered solely economic loss from a defective product, from circumventing the contractual disclaimer, limitation of remedies, and consequential damage exclusions by suing in tort, rather than on the contract. ${ }^{70}$ The theory is that the disclaimers, remedy limitations, and damage limitations were part of the bargain struck and likely resulted in a lower price for the buyer. ${ }^{71}$ In those circumstances, where the

65. 486 N.W.2d 612 (Mich. 1992).

66. Id. at 613 .

67. Id.

68. Id. at 620 .

69. Id. 1989).

70. Sunnyslope Grading, Inc. v. Miller, Bradford \& Risberg, Inc., 437 N.W.2d 213, 215 (Wis.

71. Grams v. Milk Prods., Inc., 699 N.W.2d 167, 175 n.8 (Wis. 2005). 
parties' contract anticipated the possibility of certain losses and provided for them, the parties' contract should control. The "end run" around the parties' contract to tort should not be permitted. ${ }^{72}$ There is no controversy when the defective product causes solely economic loss. ${ }^{73}$ The defective product causes no property damage, so no public safety issues are involved. The parties' contract and contract principles are considered appropriate to address the dispute between the parties.

"Other property" damage caused by a defective product, however, is normally remedied through tort, not contract law. ${ }^{74}$ The only recognized exception to that rule is when the defective product damages itself or the system of which it is an integral part. ${ }^{75}$ The disappointed expectations rule is a significant incursion into the definition of "other property." The disappointed expectations rule "governs situations in which a commercial product causes property damage but the damage... "could have been the subject of negotiations between the parties"' at the time of contracting. ${ }^{76}$ If the property damage was within the contemplation of the parties or otherwise foreseeable at the time of contracting, such property damage is not considered "other property" damage. In other words, even though the defective product has damaged "other property" that would be actionable through tort law, ${ }^{77}$ the disappointed expectations rule has created an immunity from such tort liability. The tort immunity is provided simply because the damages were foreseeable by the buyer and, thus, could have been the subject of contract negotiations.

Immunity from tort liability normally occurs through the use of an exculpatory clause in a contract. ${ }^{78}$ An exculpatory clause is a provision that relieves "a party from liability resulting from a negligent or wrongful act." "79 Clauses "intended to exculpate a party from the consequences of its own negligence are frowned upon by the law and strictly construed against the party seeking" immunity from liability. ${ }^{80}$ An exculpatory clause is obviously a significant clause in a contract, ${ }^{81}$ and, as such, one would expect to bargain

72. Bay Breeze Condo. Ass'n v. Norco Windows, Inc., 651 N.W.2d 738, 742 (Wis. Ct. App. 2002).

73. See Anzivino, supra note 1, at 1082.

74. RESTATEMENT (THIRD) OF TORTS: PRODS. LIAB. $\$ 21 \mathrm{cmt}$. e (1998).

75. Wausau Tile, Inc. v. County Concrete Corp., 593 N.W.2d 445, 453 (Wis. 1999); RESTATEMENT (THIRD) OF TORTS: PRODS. LIAB. $§ 21 \mathrm{cmt}$. e.

76. Grams, 699 N.W.2d at 175 (quoting Neibarger v. Universal Coops., Inc., 486 N.W.2d 612, 620 (Mich. 1992)).

77. Saratoga Fishing Co. v. J.M. Martinac \& Co., 520 U.S. 875, 877 (1997).

78. RESTATEMENT (SECOND) OF CONTRACTS $§ 195$ (1981).

79. BLACK'S LAW DiCTIONARY 608 (8th ed. 2004).

80. Fendley v. Power Battery Co., 561 N.Y.S.2d 760, 762 (App. Div. 1990).

81. Atkins v. Swimwest Family Fitness Ctr., 691 N.W.2d 334, 339 (Wis. 2005). 
for such protection. ${ }^{82}$ In fact, in Phillips Petroleum Co. v. Bucyrus-Erie Co. ${ }^{83}$ the Wisconsin Supreme Court specified stringent requirements that must be met to include an exculpatory clause in a contract. In Bucyrus, the buyer purchased cranes for use on offshore drilling platforms in the North Sea. ${ }^{84}$ The cranes proved defective, and the buyer sued to recover its damages. ${ }^{85}$ The seller sought to exculpate itself from all tort liability through the contractually agreed remedy of replacing any defective parts. ${ }^{86}$ The court, however, rejected the exculpatory clause as unreasonable. ${ }^{87}$ In addition to not providing a fair remedy for the buyer's losses, the court identified two other requirements that must be satisfied in order to include an exculpatory clause in a contract. First, it must be "apparent that an express bargain was struck to forego the possibility of tort recovery in exchange for negotiated alternate economic advantages, e.g., lower contract cost or express concessions on other terms." ${ }^{\prime 8}$ Second, "as a matter of public policy, [the court will] not countenance such disclaimers in the absence of such specificity in respect to the tort disclaimed." 89 In other words, an exculpatory clause in a contract will be upheld where it was expressly bargained for and the clause clearly specifies the tort disclaimed.

The disappointed expectations rule clearly violates both tenets required by Bucyrus. First, the tort immunity provided by application of the rule is not bargained for by the seller/manufacturer. In application, the seller/manufacturer is granted tort immunity automatically if the buyer does not anticipate his potential damages and provide for some protection from them. Second, as a matter of public policy, a valid exculpatory clause must clearly specify the tortious conduct that is being exculpated. The disappointed expectations rule provides tort immunity for the seller/manufacturer from all damages that were foreseeable or within the contemplation of the parties at the time of contract formation. There is no specificity requirement. Thus, the disappointed expectations rule also fails the specificity requirement. In sum, the disappointed expectations rule severely distorts the free bargaining between a buyer and a seller in favor of the seller/manufacturer by providing un-bargained for and nonspecific tort immunity.

\footnotetext{
82. See E. River S.S. Corp. v. Transamerica Delaval, Inc., 476 U.S. 858, 872-73 (1986).

83. 388 N.W.2d 584 (Wis. 1986).

84. Id. at 586.

85. Id.

86. Id. at 588 .

87. Id. at 591 .

88. Id. at 589 (citing Arnold v. Shawano County Agric. Soc'y, 330 N.W.2d 773, 779 (Wis.

89. Id.
} 1983)). 


\section{B. The Disappointed Expectations Rule Essentially Destroys the "Other Property" Exception to the Economic Loss Doctrine}

The impact of adopting the disappointed expectations rule is to destroy the general tort rule that damage to "other property" is recoverable through tort law. The disappointed expectations rule provides that when a defective product causes property damage and that damage was foreseeable at the time of contracting, the buyer can pursue only contract remedies, not tort. ${ }^{90}$ The test is uniformly understood to be a reasonably foreseeable test. ${ }^{91}$ In other words, "when a defective product causes damage to [']other property['] in a manner that was reasonably foreseeable at the time of contracting, the damage is considered economic loss." 92 On the other hand, "when [the defective product] causes damage in a manner that was not reasonably foreseeable," the damage is considered "other property" damage and is actionable under tort law. ${ }^{93}$ In essence, the critical distinction between whether contract law or tort law is available under the disappointed expectations test is the foreseeability of the property damage at the time of contracting.

Foreseeability is a well-recognized requirement for the recovery of damages. Damages must be foreseeable under both contract law ${ }^{94}$ and the U.C.C. ${ }^{95}$ In addition, damages must also be foreseeable under both negligence ${ }^{96}$ and strict liability. ${ }^{97}$ The damages must be a foreseeable consequence of the breach for contracts, U.C.C., and negligence. For strict liability, the manufacturer is responsible for the damages caused by a defective product's foreseeable use. ${ }^{98}$ In any event, foreseeability is a requirement to be satisfied before recovery is permitted under either contract law or tort law.

It is axiomatic that tort law permits recovery from a manufacturer and others in the distributive chain for foreseeable physical harm to property caused by product defects. ${ }^{99}$ The problem with the disappointed expectations rule is that it destroys the foregoing axiom. If a defective product causes

90. Rich Prods. Corp. v. Kemutec, Inc., 66 F. Supp. 2d 937, 973 (E.D. Wis. 1999); Grams v. Milk Prods., Inc., 699 N.W.2d 167, 175 (Wis. 2005).

91. Rich, 66 F. Supp. 2d at 972-73; Grams, 699 N.W.2d at 182 (Abrahamson, C.J., dissenting); see also supra Part III.

92. Rich, 66 F. Supp. $2 d$ at 973 (internal quotation added).

93. Id.

94. RESTATEMENT (SECOND) OF CONTRACTS § 351 (1981).

95. U.C.C. § 2-715(2)(b) (2003); WIS. STAT. § 402.715(2)(b) (2007-2008).

96. RESTATEMENT (SECOND) OF TORTS $§ 435$ (1965).

97. Restatement (Third) OF Torts: Prods. Liab. § 2, § $16 \mathrm{cmt}$. a, $\S 10 \mathrm{cmt}$. b, illust. 1 (1998)

98. Id. $\S 1 \mathrm{cmt}$. a.

99. Saratoga Fishing Co. v. J.M. Martinac \& Co., 520 U.S. 875, 879 (1997). 
"other property" damage and the court finds such damage was foreseeable at the time of contracting, all tort theories are precluded. In other words, the only circumstance where one could pursue tort theories for "other property" damages would be when those damages were not foreseeable at the time of contracting. However, if the damages are not foreseeable for contract purposes, they are likely not foreseeable for tort purposes either.

The courts have recognized this consequence. In Messer Griesheim Industries, Inc. v. Cryotech of Kingsport, Inc. ${ }^{100}$ a distributor of liquid carbon dioxide sued its producer for damages that arose from the retail sale of contaminated carbon dioxide. ${ }^{101}$ Liquid carbon dioxide is used at the retail level for various food and medical purposes. ${ }^{102}$ The distributor sued under negligence and strict liability and claimed that the contaminated carbon dioxide caused "other property" damage. ${ }^{103}$ In particular, the damage claimed to be "other property" damage was (1) damage to the distributor's storage tanks; (2) contamination of the distributor's other liquid carbon dioxide by mixing in the contaminated carbon dioxide; (3) its customers' soft drinks were rendered unsalable; and (4) its customers' soft drink cans were ruined. ${ }^{104}$ The producer argued that "other property" does not include the type of property that one would reasonably expect to be injured as a direct consequence of the failure of a defective product. ${ }^{105}$ The producer argued that the distributor's losses were essentially damages for failed commercial expectations and not recoverable in tort. ${ }^{106}$ The court acknowledged the logic of the producer's argument by noting that "the most obvious consequence of a noncompliance with contract[] specifications for food grade carbon dioxide would be ruination of any food or drink product into which the [contaminated] carbon dioxide was combined." 107

The court, however, rejected the application of the disappointed expectations rule. ${ }^{108}$ The court noted "that if all property that one would reasonably expect to be injured because of the defective product is excluded from the definition of 'other property," the result would be that a buyer could never recover from a manufacturer in tort for property damage. ${ }^{109}$ The court reasoned that a plaintiff in a tort case must establish "that the harm giving rise

100. 131 S.W.3d 457 (Tenn. Ct. App. 2003).

101. Id. at 460 .

102. See id.

103. Id. at 463 .

104. Id.

105. Id. at 465 .

106. Id.

107. Id. at 465-66 (internal quotation omitted).

108. Id. at 466 .

109. Id. 
to the cause of action was reasonably foreseeable."110 Thus, under the disappointed expectations rule, by establishing the damages were reasonably foreseeable, "the plaintiff in a tort action against a manufacturer [has] necessarily eliminate[d] its damaged property from the category of 'other property' and...thereby[] undermin[ed] its case."111 After rejecting the disappointed expectations rule, the court held that the distributor could sue in tort for damage to the "other property." 112

The Messer court clearly and correctly identified the consequence of adopting the disappointed expectations rule. Because foreseeability is a prerequisite for both contract and tort recovery, once the "other property" damage is classified as foreseeable in the tort case, it becomes foreseeable under the disappointed expectations test, which thereby precludes the tort action. In essence, the disappointed expectations test virtually eliminates tort actions for "other property" damage caused by a defective product.

\section{The Disappointed Expectations Rule Undercuts the Public Policy that Requires Sellers/Manufacturers to Produce and Promote Safe Products}

The disappointed expectations rule undercuts the societal concern for safety by removing the tort incentive for manufacturers to produce safer products. The rule has that effect because all reasonably foreseeable property damage resulting from a defective product is not recoverable in tort. Both contract law and tort law are based on the concept of duty. ${ }^{113}$ The duty under contract law arises from a consensual arrangement between two parties that bargain. ${ }^{114}$ Tort duties, on the other hand, arise from obligations imposed on members of society by law. ${ }^{115}$ A seller/manufacturer necessarily incurs both contract and tort duties when selling a product. The determination of whether a manufacturer has assumed contract or tort duties "rests ... on an understanding of the ... responsibilit[ies] a manufacturer must undertake in distributing [its] product."116 "The law imposes tort duties upon [a] manufacturer[] to protect society[] ... from the physical harm ... [that] may result from defective products." ${ }^{117}$ Contract law seeks to hold parties to their promises and thereby insure that each party receives the benefit of his bargain. $^{118}$

\footnotetext{
110. $I d$.

111. Id.

112. Id.

113. See Daanen \& Janssen, Inc. v. Cedarapids, Inc., 573 N.W.2d 842, 846 (Wis. 1998).

114. Id.

115. See E. River S.S. Corp. v. Transamerica Delaval, Inc., 476 U.S. 858, 871 (1986).

116. Id.

117. Linden v. Cascade Stone Co., 699 N.W.2d 189, 193 (Wis. 2005).

118. Daanen \& Janssen, Inc., 573 N.W.2d at 846.
} 
It is generally agreed that important policy reasons exist for redressing product-quality defects through contract law and safety concerns through tort law. ${ }^{119}$ "Products liability [law] grew out of a public policy judgment that people needed more protection from dangerous products than is afforded by" contract law. ${ }^{120}$ Holding manufacturers liable for any personal injury or property damage caused by a defective product protects safety concerns. ${ }^{121}$ "[Property] damage is considered so akin to personal injury [damage] that the two are treated alike" under product liability law. ${ }^{122}$ "One important purpose of defective-product tort law is to encourage the manufacture of safer products." 123 Tort rules are designed "to provide appropriate safe-product incentives." 124 Any attempt to diminish that basic incentive requires a justification. ${ }^{125}$ Simply because tort and contract liability overlap is no justification for supplanting the ordinary rule of tort liability that applies when a product causes "other property" damage. ${ }^{126}$

Every time a product is purchased and fails, there are disappointed expectations. The U.C.C. recognizes that a buyer purchases a product for its general $^{127}$ or specialized ${ }^{128}$ purpose. When that purpose is not fulfilled, a disappointed expectation occurs. The disappointed expectations rule essentially destroys all tort claims where a product's failed performance causes "other property" damage. ${ }^{129}$ The avowed reason for endorsing the disappointed expectations rule is that the buyer should have foreseen the incurred damages and provided for his own protection through negotiated warranties, remedies, or insurance. ${ }^{130}$ How can the fact that a buyer could have contracted for some form of damage protection (hypothetical contract) address the societal concern for safer products? It does not. In fact, the doctrine actually undercuts the societal concern by removing the tort incentive from the manufacturer to produce a safer product. Is there a sufficient justification to deny the tort approach in favor of a contract approach to "other property" damage? The interests to be balanced are the societal concern for safer products versus the interest in having buyers foresee "other property"

119. Northridge Co. v. W.R. Grace \& Co., 471 N.W.2d 179, 185 n.11 (Wis. 1991).

120. E. River, 476 U.S. at 866.

121. Gen. Cas. Co. v. Ford Motor Co., 592 N.W.2d 198, 200-01 (Wis. 1999).

122. E. River, 476 U.S. at 867.

123. Saratoga Fishing Co. v. J.M. Martinac \& Co., 520 U.S. 875, 881 (1997).

124. $I d$.

125. Id.

126. Id. at $882-83$.

127. U.C.C. $\S 2-314$ (2003); WIS. STAT. $\$ 402.314$ (2007-2008).

128. U.C.C. § 2-315 (2003); WIS. STAT. § 402.315 (2007-2008).

129. See supra Part III.

130. See Grams v. Milk Prods., Inc., 699 N.W.2d 167, 172 (Wis. 2005). 
damages in the event of a product's failed performance and negotiating some protection. The greater interest is to continue to place the burden on manufacturers to produce safer products through tort liability. The disappointed expectations rule unfortunately focuses on the possibility that a buyer could have negotiated protection from property damage caused by a defective product, rather than focus on the manufacturer's duty to produce a safer product. In other words, if the buyer fails to negotiate for contract protection from foreseeable property damage, the buyer loses the right to pursue tort recovery. Such a rule fails to serve the public policy of promoting safer products.

\section{The Disappointed Expectations Rule Is an Enigma to Comprehend and Apply}

The first state to adopt the reasonably foreseeable test of the disappointed expectations rule was Michigan. ${ }^{131}$ In Neibarger v. Universal Cooperatives, Inc., ${ }^{132}$ dairy farmers purchased a milking system to milk their cows. ${ }^{133}$ After the system was in operation for a period, the cows became ill and died, or had to be sold for beef. ${ }^{134}$ The vacuum system on the milking equipment was defective. ${ }^{135}$ The farmers sued on contract and tort theories to recover their losses. ${ }^{136}$ The main issue before the court was whether the contract or tort statute of limitations should apply. ${ }^{137}$ By the time the case was filed, the contract statute of limitations had expired, but the tort statute of limitations had not. ${ }^{138}$ In discussing the economic loss doctrine, the court explained that the doctrine turns "on a distinction drawn between transactions involving the sale of goods for commercial purposes where economic expectations are protected by commercial and contract law, and those involving the sale of defective products to individual consumers who are injured in a manner . . traditionally ... remedied by resort to" tort law. ${ }^{139}$ In Neibarger, the defective milking system damaged more than itself; it damaged the farmers' cows, which were "other property." The court noted that in many cases, failure of a product to perform as expected might result in damage to "other property." 140 The court characterized the foreseeable "other property"

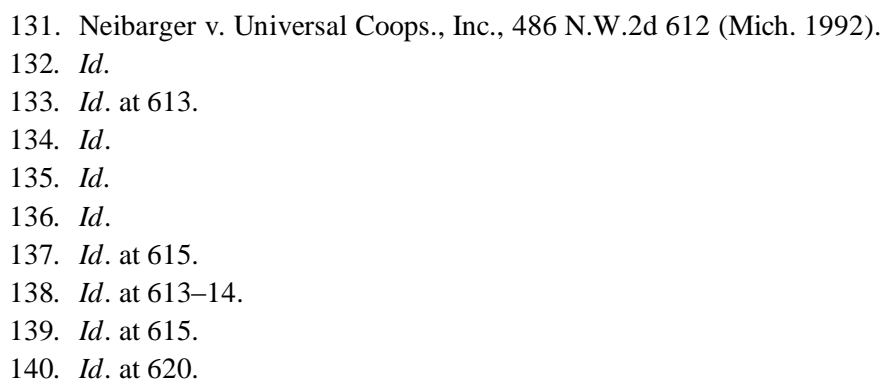


damage caused by the defective milking system to the cows as a "common problem for dairy farmers" 141 and a "normal part of the dairy business." 142 As a result, the court held that the damages were reasonably foreseeable "other property" damage at the time of contracting and only recoverable through the U.C.C., not tort law. ${ }^{143}$

Another case that suggests how to interpret the reasonably foreseeable test is Detroit Edison Co. v. NABCO, Inc. ${ }^{144}$ In Detroit Edison, a utility company contracted with NABCO to supply pipe to be used in its power plant. ${ }^{145}$ The pipe was used to carry steam. ${ }^{146} \mathrm{~A}$ number of years after installation, one of the pipes burst, injuring seventeen people and causing significant property damage. ${ }^{147}$ Detroit Edison filed a products liability action to recoup its \$20 million in damages. ${ }^{148}$ NABCO defended on the basis that the tort claims were barred by the economic loss doctrine and Detroit Edison's sole remedy was under the U.C.C. ${ }^{149}$ The Sixth Circuit applied the Neibarger analysis. ${ }^{150}$ The court reasoned that Neibarger requires a court to focus "on the parties involved and the nature of the product's use." ${ }^{\prime 51}$ The court held that it was "foreseeable that pipes ... that [carry] steam at high temperatures and high pressures could explode upon failure." 152 The court characterized the damages caused by the explosion as an "inherent hazard[]." 153 The court concluded that the consequences of this inherent hazard were reasonably foreseeable. ${ }^{154}$

The Neibarger decision figured prominently in the Grams court's adoption of the disappointed expectations rule. ${ }^{155}$ The Grams court, however, has provided conflicting signals on how to apply the rule. As an initial matter, the court indicated that this foreseeability rule "does not mean that contract principles will envelop all damages foreseeable in a remote or general sense." $" 156$ In other words, the reasonably foreseeable test will not cover all

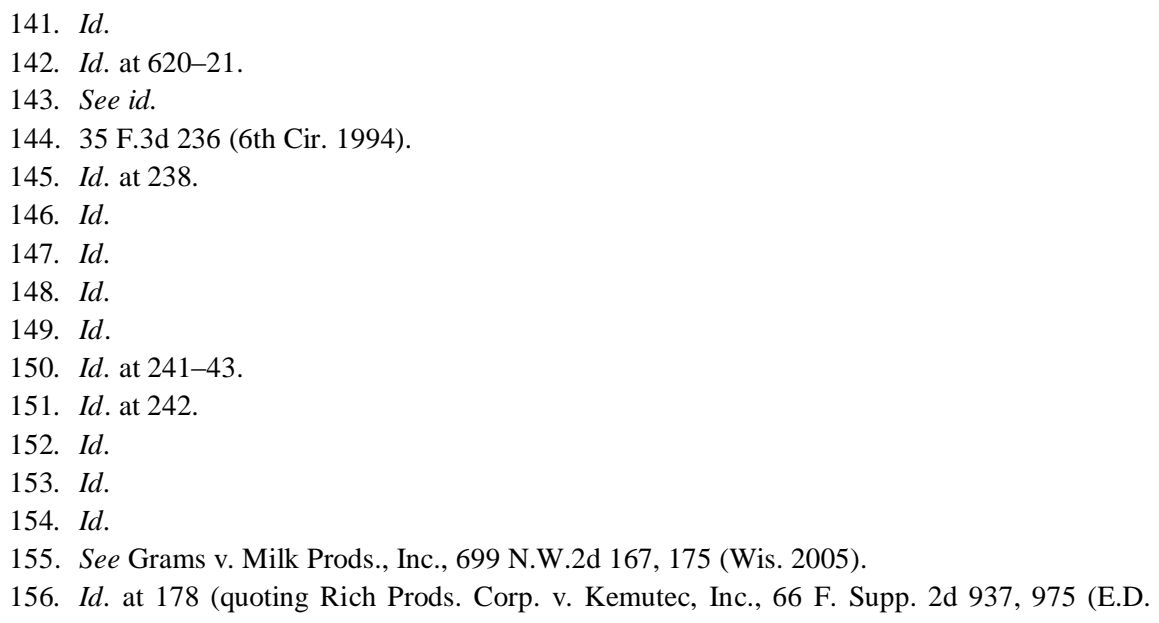


foreseeable property damage. Rather, the Grams court offers the limitation that "the economic loss doctrine will [only] apply when "prevention of the subject risk was one of the contractual expectations motivating the purchase of the defective product." 157 The court suggested such a determination requires a two-step inquiry. ${ }^{158}$ The first inquiry is to determine the buyer's expectations. ${ }^{159}$ In Grams, the court concluded that the milk substitute was purchased to foster the healthy development and growth of young calves. ${ }^{160}$ The second inquiry is to determine whether the aggrieved buyer's claim is "about disappointment with those expectations." I61 In Grams, the court concluded that the product malnourished and killed the calves, which was a prime example of the disappointed expectations rule. ${ }^{162}$ The problem with the offered limitation is that every product has a purpose for which it is purchased, and every buyer is disappointed when the product fails to perform as expected. ${ }^{163}$ Virtually all damages that flow from such disappointment are foreseeable damages and under the disappointed expectations test, precluded from tort recovery. The Grams limitation suggests that there are "other foreseeable damages" that would somehow qualify for tort recovery. The limitation offers a distinction that is impossible for the courts to apply. Courts are skilled at distinguishing foreseeable from unforeseeable damages ${ }^{164}$ but not at distinguishing one type of foreseeable damage from another type of foreseeable damage. This is a prescription for inconsistent and contradictory decisions.

The application of the disappointed expectations rule is not a simple matter, and the Grams court acknowledged such. ${ }^{165}$ The court offered a hypothetical to illustrate the difference between foreseeable damages that are covered by the disappointed expectations rule, and other damages that would not be foreseeable and recoverable through tort. ${ }^{166}$ In Selzer v. Brunsell Bros., the buyer bought windows that were treated against rot and decay. ${ }^{167}$ Seven years after the windows were installed, the windows were rotting and the rot

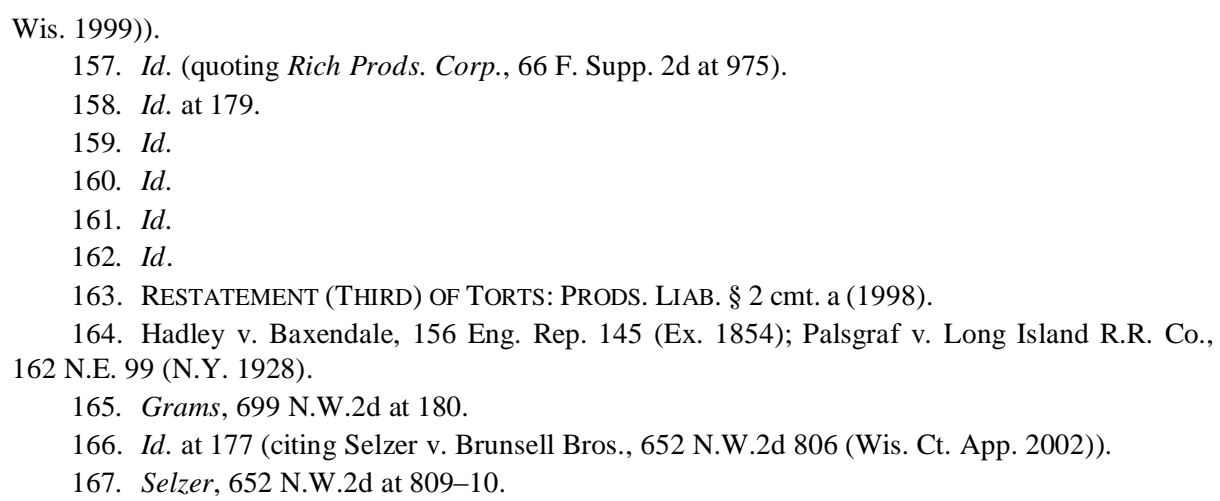


spread to the siding around the window. ${ }^{168}$ The court noted that the rot in the wood surrounding the windows was a direct consequence of the rot in the windows themselves. ${ }^{169}$ Therefore, the collateral rot was a part of the buyer's disappointed expectations. ${ }^{170}$ On the other hand, had the windows not rotted, "but spontaneously shattered, spewing shards of glass into an adjacent Picasso," such damage would have occurred "in an entirely unanticipated manner, going well beyond a failure to perform as expected and entitling [the buyer] to pursue a tort remedy." 171 In other words, the disappointed expectations rule would not apply because the damages would not have been foreseeable at the time of contracting. The colorful hypothetical illustrates how very remote the damage occurrence must be to qualify for tort recovery.

The cases decided after Grams have attempted to glean its meaning but necessarily have encountered significant difficulties. In Foremost Farms USA Coop. v. Performance Process, Inc. ${ }^{172}$ a buyer purchased a defoamer to be used in the production of its food products. ${ }^{173}$ The purpose of the defoamer was to reduce foaming during the process of manufacturing food products. ${ }^{174}$ Unfortunately, the defoamer was contaminated with a foreign substance and spoiled the buyer's food products. ${ }^{175}$ The buyer sought to recoup its significant losses ${ }^{176}$ through tort theories. ${ }^{177}$

The tort theories were alleged on the basis that the defective defoamer damaged the food products, which were "other property." 178 The court identified the dispositive issue as whether the damaged food products qualified as "other property." 179 The court correctly noted that there are two tests utilized by the courts to determine whether damaged property is "other property"- the integrated systems test and the disappointed expectations test. ${ }^{180}$ The integrated systems test was not determinative because the food products and defoamer were not part of an integrated system. ${ }^{181}$ Thus, the court focused on application of the disappointed expectations test. ${ }^{182}$

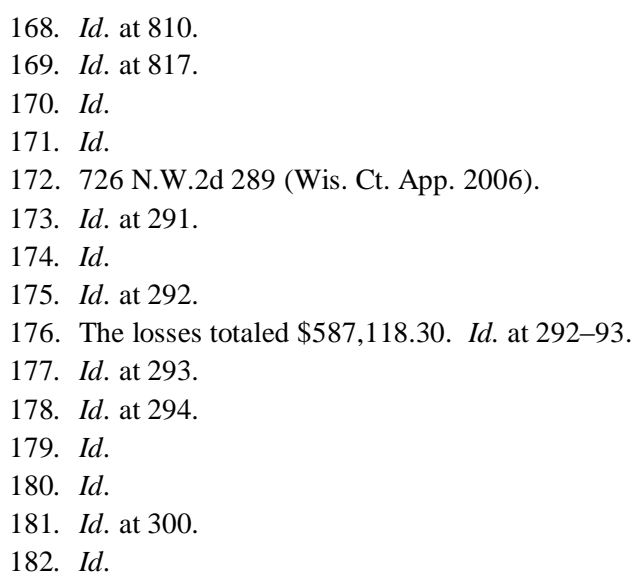


The court gleaned from Grams that the disappointed expectations test is directed at determining whether a buyer should have foreseen the need to protect itself against the incurred losses through its contract. ${ }^{183}$ More specifically, "[t]he test focuses on the expected function of the product" and whether the purchaser should have reasonably foreseen that the product could cause the "other property" damage. ${ }^{184}$ More simply, the court stated that the question is "whether a reasonable purchaser in the plaintiff"s position should have foreseen the risk." "185 If so, the matter should have been dealt with in the contract, thus precluding a buyer from asserting tort theories. The core issue was whether the damages incurred were reasonably foreseeable. ${ }^{186}$ The court concluded that the damaged food products were not a foreseeable consequence from a defective defoamer. ${ }^{187}$ The court noted that determining whether damages are reasonably foreseeable is necessarily fact-intensive. ${ }^{188}$ Some situations are "so obviously not susceptible to reasonable anticipation that no further inquiry is needed to conclude that the "disappointed expectations' test is not met." " For example, "[n]o one expects a glass window to spontaneously shatter and damage a nearby object." ${ }^{190}$ The purchaser of a window would not reasonably foresee such an occurrence. "On the other hand, [where] a product is purchased to nourish calves, ... a reasonable purchaser should anticipate damage to the calves and bargain accordingly." 191

The Foremost court offered those examples to illustrate the opposite ends of the foreseeability spectrum, and it noted that the cases in between will necessarily be difficult to resolve. ${ }^{192}$ The court did, however, offer a number of factors that must be considered in determining whether the damages incurred were reasonably foreseeable. ${ }^{193}$ Those factors include "the purpose for purchasing the product, the reasonableness of anticipating a risk of the product's failed performance, the availability of warranties or risk sharing mechanisms, ... the extremity of the facts, ${ }^{194}$ and the likelihood that the

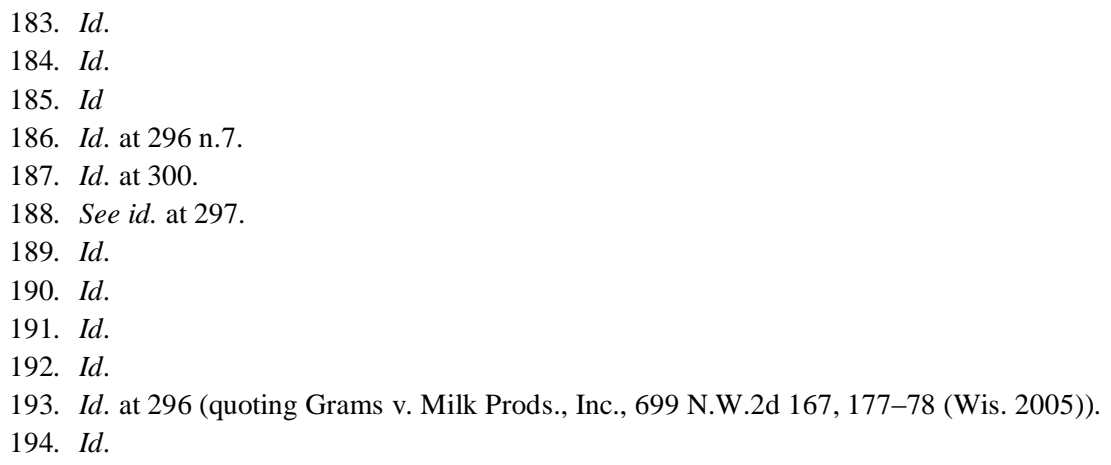


product will interact with other products or property. ${ }^{195}$ In Foremost, the court framed the question as whether the buyer "should have anticipated that the defoamer might function properly as a defoamer, yet contain a contaminant" that might damage the buyer's food products. ${ }^{196}$ Framed as such, the court held that there was no evidence to suggest that the buyer should have reasonably foreseen "that the defoamer would contain a contaminant ... that would render [the buyer's food] products unfit for human consumption." 197 Therefore, the elements of the disappointed expectations rule were not satisfied, with the consequent result that the defoamer's damage to the food products qualified as damage to "other property." 198

It is critical to note that how the court frames the issue will likely determine the outcome under the disappointed expectations rule. For example, had the court in Foremost framed the issue to be whether it was reasonably foreseeable that a defective defoamer used in a food manufacturing process could damage the manufactured food products, the court likely would have reached a different result. Rather, the court framed the issue as whether the buyer should have foreseen that the defoamer would contain a contaminant that might damage the food products. ${ }^{199}$ The reasonable foreseeability was focused on the nature of the defect rather than the foreseeability of the damage that might be caused by the defect. The focus as required by Grams, however, should be on the foreseeability of the damages as a result of a failed performance, ${ }^{200}$ not the nature of the defect or the reason for the failed performance. The question should have been whether it was reasonable to foresee that a defective defoamer used in a manufacturing food process would damage the food products.

Framed differently, the Foremost outcome is not free from doubt. A similar issue arose in Wilson v. Tuxen, ${ }^{201}$ where the buyers purchased dairy cattle for their farm. ${ }^{202}$ Within several months of purchase, the cows exhibited a fatal, contagious disease that required their slaughter. ${ }^{203}$ In addition, the diseased cows infected a calf owned by the buyers that was not purchased from the sellers. ${ }^{204}$ The farmers sued in contract and tort to recover their

195. Id.

196. Id. at 300 .

197. Id.

198. Assuming on remand that the defoamer and food products are held not to be part of an integrated system.

199. Foremost, 726 N.W.2d at 300.

200. Grams v. Milk Prods., Inc., 699 N.W.2d 167, 178 (Wis. 2005).

201. 754 N.W.2d 220 (Wis. Ct. App. 2008).

202. Id. at 224 .

203. Id.

204. Id. at 226 . 
losses. ${ }^{205}$ The buyers argued that the purchased cows were "other property" because they were not part of an integrated system nor were the damages foreseeable. ${ }^{206}$ In addition, the buyers argued that "other property" was damaged because the purchased cows infected their other calf that was not part of the transaction. ${ }^{207}$ The buyers asserted that the correct question under the disappointed expectations rule was whether they should have reasonably foreseen that the purchased cows would have had a fatal, infectious disease. ${ }^{208}$

The court disagreed with that formulation; rather, the court held that the correct question was whether the buyers should have foreseen that the cows would fail to produce. ${ }^{209}$ The court rejected the notion that the question was whether the buyers should have foreseen "the risk that the cows might be infected with a particular ailment." 210 The court concluded that the case was similar to Grams in that the cows' failure to produce milk as expected was contrary to the buyers' expectations of the cows' performance. ${ }^{211}$ The court noted that no fact finding would be necessary under the disappointed expectations rule because the record points in only one direction-the damages were foreseeable. ${ }^{212}$

However, even though the buyers failed under the disappointed expectations rule, the court held that the buyers were able to pursue their damages through tort theories because the diseased cows infected the nondiseased calf, which qualified as "other property" damage. ${ }^{213}$ During the negotiation process, the buyers asked the seller if the seller ever had any problems with the particular disease in his herd. ${ }^{214}$ The court noted that the buyers knew there was some risk that the disease might be in the purchased cows. ${ }^{215}$

Given the foreseeability that the disease could be present in the herd, perhaps the correct question under the disappointed expectations test should have been whether a reasonable buyer should have reasonably foreseen that mixing infected cows with healthy cows could infect the healthy ones. Under such phrasing, the damage to the "other calf" would have been reasonably foreseeable under the disappointed expectations test and thereby preclude any 
tort claim. It seems reasonably foreseeable that placing otherwise healthy cows with cows with a fatal, contagious disease will likely cause the healthy cows to become infected.

Another illustration of a court's framing of the issue as the determinative factor is Coach USA, Inc. v. Van Hool N.V. ${ }^{216}$ In Coach USA, a bus was leased for use in a charter business. ${ }^{217}$ On one particular charter, a fire destroyed the bus and the passengers' personal property. ${ }^{218}$ The lessee sued the manufacturer and lessor on tort theories. ${ }^{219}$ The lease agreement between the parties disclaimed all warranties, excluded consequential damages, and provided that the lessee was to indemnify the lessor for any liability arising out of the use or operation of the bus. ${ }^{220}$ The court ruled that the baggage and other personal property of the passengers was not integrated into the bus and, as such, did not fall within the integrated systems rule. ${ }^{221}$ However, the court reasoned that the bus was leased "for the purpose of transporting passengers and their personal property from one location to another."222 Further, the lease agreement specifically mentioned liability for personal property. ${ }^{223}$ Therefore, the damages sought by the lessee were reasonably foreseeable damages that could result from the bus's failed performance. As such, the damages fell within the disappointed expectations rule and were not damage to "other property." 224 Significantly, the court focused on the foreseeability of the damages that would follow from a failed performance of the bus, and not on the foreseeability of the manner or means that caused the damages - the fire. 225

In discussing the scope of foreseeable damages under the disappointed expectations test, the Grams court also stated that "[i]f a product is expected and intended to interact with other products and property, it naturally follows that the [purchased] product could adversely affect and even damage" such other products and property. ${ }^{226}$ Clearly, this is a broad statement of the scope of damages covered by the disappointed expectations rule. Property that is expected and intended to interact with the product and is naturally damaged by the defective product falls within the coverage of the disappointed

216. No. 06-C-457-C, 2006 U.S. Dist. LEXIS 88783 (W.D. Wis. Dec. 5, 2006).

217. Id. at *3.

218. Id. at $* 5$.

219. Id. at *5-7.

220. Id. at *3-4.

221. Id. at $* 13$.

222. Id. at *13-14.

223. Id. at *14.

224. Id.

225. See id. at *11-14.

226. Grams v. Milk Prods., Inc., 699 N.W.2d 167, 179 (Wis. 2005). 
expectations rule. The court's statement of the scope of the rule is unquestionably as broad as the traditional standards of foreseeability under contract, ${ }^{227}$ U.C.C. ${ }^{228}$ and tort law. ${ }^{229}$

At the same time that the Grams court stated that the rule covers property that is expected and intended to interact with the defective product and that could naturally be damaged by it, the court rejected any rule that would include an inquiry based on the kind of property harmed. ${ }^{230}$ In the court's opinion, a focus on the kind of property harmed would eventually "cause the erosion of the U.C.C." and destroy "the fundamental distinction between contract and tort" law. ${ }^{231}$ Rather, the court concluded that "[a] rule that allows tort recovery based on what is damaged, rather than whether the risk of that damage was within the scope of the bargain, would leave little room for contract.",232

The conflict between damages that result from foreseeable interaction and damages that could have been within the scope of the bargain was also addressed in Foremost. ${ }^{233}$ The Foremost court, when discussing reasonable foreseeability, noted that despite the Grams court's statement to the contrary, reasonably foreseeable "should not be equated with 'foreseeable interaction' between the purchased product and the damaged property." 234 As an initial matter, the court noted that the term "interact" is ambiguous and subject to different meanings. ${ }^{235}$ However, once that ambiguity is resolved, the court stated that foreseeable interaction, by itself, does not establish that damage was reasonably foreseeable within the meaning of the disappointed expectations test. ${ }^{236}$ Rather, the court said that "foreseeable interaction is a factor to consider when applying the 'disappointed expectations' test, but is not, by itself, sufficient to satisfy the test."237

The Grams court's explanation of the disappointed expectations rule presents difficult interpretation issues for the courts and the practicing bar. The Grams court indicated foreseeable damages include property damage that is a result of foreseeable interaction with other property. The Foremost court

227. Restatement (SECOND) OF CONTRACTS $\$ 351$ (1981).

228. U.C.C. § 2-715 (2003); WIS. STAT. § 402.715 (2007-2008).

229. Palsgraf v. Long Island R.R. Co., 162 N.E. 99 (N.Y. 1928).

230. Grams, 699 N.W.2d at 178 .

231. Id. (internal quotation marks omitted).

232. Id. at 179 .

233. Foremost Farms USA Coop. v. Performance Process, Inc., 726 N.W.2d 289, 295-96 (Wis. Ct. App. 2006).

234. Id.

235. See id. at 296 n.7.

236. Id. at 296 .

237. Id. 
explained that foreseeable interaction is only a factor in applying the disappointed expectations test. Thus, some foreseeable interaction is covered by the rule, and some foreseeable interaction is not. The Grams court expressly stated that not all foreseeable damages fall within the scope of the disappointed expectations rule. The only damages covered are those damages that were within the contemplation of the parties or those that, at the time of contracting, were a foreseeable result of the failure of the product to meet its expectations. Thus, some foreseeable damages are covered by the rule and some foreseeable damages are not. Courts have little experience in distinguishing one type of foreseeable damage from another. Also, how the court frames the issue under the disappointed expectations test is critical. Notably, whether the court frames the issue as the foreseeability of the damages or the event causing the damages will determine the outcome of the disappointed expectations test. The disappointed expectations rule is clearly difficult to comprehend and very problematic to apply in a fair and consistent fashion.

\section{E. The Disappointed Expectations Rule Places the Burden to Ensure Contract Coverage for Reasonably Foreseeable Property Damage on the Wrong Party}

The disappointed expectations rule places the burden on the buyer to assume, allocate, or insure against the risk that the product will prove defective. The assumption is that the buyer is best able to foresee the damages a defective product might cause the buyer. ${ }^{238}$ It would seem equally reasonable to place this risk on the seller/manufacturer since the seller has the most experience with the kind of damage its defective product has actually caused. Nevertheless, the question should be which party is more likely to introduce the prospect of damages into the contract negotiations. At least one court has seriously questioned whether the buyer is the best party on which to place the burden of negotiating for future damages. In Foremost Farms USA Cooperative v. Performance Process, Inc., ${ }^{239}$ a buyer purchased a defoamer that subsequently proved defective and contaminated food products that the buyer produced. ${ }^{240}$ In discussing whether the buyer is the best party to foresee future damages by a defective product, the court offered some rhetorical questions that challenged the assumption that the buyer is the best party to foresee damages. ${ }^{241}$ When referencing a dispute between a farmer and its

238. Grams v. Milk Prods., Inc., 699 N.W.2d 167, 172 (Wis. 2005).

239. 726 N.W.2d 289 (Wis. Ct. App. 2006).

240. Id. at 292.

241. Id. at 297. 
chemical supplier over a defective crop spray, ${ }^{242}$ the court asked "do farmers ... normally know that a chemical applied to crops for one purpose might cause harm in a manner unrelated to the expected function of the chemical?"243 "To what extent are ...farmers expected to contemplate possible damage scenarios?" 244 The court noted that a careful buyer might "anticipate the desirability of obtaining [broad] contractual protection ... against all damage caused by a defective product," but "no manufacturer or distributor would agree to such far-reaching liability." 245 In addition, the court noted that in many cases, the buyer's bargaining position is extremely disparate. ${ }^{246}$ Thus, the possibility of a buyer negotiating protection in the contract is primarily theoretical. As a result, the buyer is discouraged from introducing the issue into the negotiations.

The buyer is clearly not the best party to ensure that the prospect of reasonably foreseeable damages is introduced into contract negotiations. The seller/manufacturer also has no incentive to raise the issue because the disappointed expectations test precludes tort recovery for all "reasonably foreseeable" damages. Therefore, the seller/manufacturer is protected from tort liability by the buyer's failure to address the issue. ${ }^{247}$ As a result of placing the bargaining burden on the buyer, the disappointed expectations test actually has incentives to avoid addressing foreseeable damages in the parties' contract. The disappointed expectations rule has the opposite impact than what was intended.

\section{F. The Disappointed Expectations Rule Has Been Rejected by the United States Supreme Court}

In Saratoga Fishing Co. v. J.M. Martinac \& Co. ${ }^{248}$ a shipbuilder installed a new hydraulic system in a new ship. ${ }^{249}$ After the ship was sold to the initial user, the initial user added new equipment to the ship. ${ }^{250}$ Subsequently, the initial owner sold the ship to a second owner. ${ }^{251}$ Thereafter, the ship caught fire and sank due to a defect in the original hydraulic system. ${ }^{252}$ The second

242. See Tony Spychalla Farms, Inc. v. Hopkins Agric. Chem. Co., 444 N.W.2d 743 (Wis. Ct. App. 1989).

243. Foremost, 726 N.W.2d at 297.

244. Id.

245. Id.

246. Id. at $297 \mathrm{n} .8$.

247. See supra Part IV.A.

248. 520 U.S. 875 (1997).

249. Id. at 877 .

250. Id.

251. $I d$.

252. Id. 
owner sought to recover its losses through tort theories on the basis that the defective product (hydraulic system) damaged "other property" (the new equipment added to the ship). ${ }^{253}$ The court held that the added equipment did constitute "other property;" "254 thus, the second owner was permitted to utilize tort theories to recoup its loss. ${ }^{255}$ In analyzing the case, the court made the following statement:

Of course, nothing prevents a user/reseller from offering a warranty. But neither does anything prevent a Manufacturer and an Initial User from apportioning through their contract potential loss of any other items - say, added equipment or totally separate physical property-that a defective manufactured product, say, an exploding engine, might cause. No court has thought that the mere possibility of such a contract term precluded tort recovery for damage to an Initial User's other property. ${ }^{256}$

The court initially noted that a manufacturer and buyer can, through their contract, apportion for any loss to "other property" that a defective product might cause. ${ }^{257}$ Significantly, the court concluded that no court had thought that the mere possibility of such a contract term should preclude tort recovery for damage to "other property." "258 In fact, the U.S. Supreme Court has accurately predicted the impact of the disappointed expectations test. The disappointed expectations test precludes tort recovery where the damage to the buyer's "other property" could have been the subject of negotiations between the buyer and seller. In other words, the mere possibility of addressing the "other property" damage in the parties' contract precludes tort liability. This is precisely the kind of intrusion of contract principles into tort law that the Court rejected.

\section{G. The Disappointed Expectations Rule Violates the U.C.C. Policy of Bargaining for an Exclusive Remedy}

The rules stated in the U.C.C. are default rules that apply in the absence of contrary agreement. ${ }^{259}$ The U.C.C. expressly provides that the rules within

253. Id.

254. Id. at 884 .

255. See id. at 878,885 .

256. Id. at 882 .

257. Id.

258. Id.

259. U.C.C. § 1-302 (2003); WIS. STAT. § 401.102(3) (2007-2008). 
the U.C.C. can be changed by the parties' contract, ${ }^{260}$ with some exceptions. ${ }^{261}$ The U.C.C.'s warranty rules define the performance expectations for a product. ${ }^{262}$ When a product fails to meet its performance expectations, the U.C.C. also specifies the remedies available to an aggrieved buyer. $^{263}$ Specifically, the U.C.C. permits a seller/manufacturer to contractually modify or limit the remedies available to an aggrieved party for damages sustained as a result of a defective product. ${ }^{264}$ The damages specified by the U.C.C. include property damage caused by a product's failure to meet its performance expectations. ${ }^{265}$ Specifically, the U.C.C. provides that the parties' contract "may limit or alter the measure of damages recoverable... as by limiting the buyer's remedies ... to repair [or] replacement." "266 Further, the U.C.C. mandates that the buyer's resort to any remedy "is optional unless the remedy is expressly agreed to be exclusive, in which case it is the sole remedy." 267 Therefore, under the U.C.C. the only way a remedy can be mandated as the sole remedy is if the parties' agreement expressly so provides. The U.C.C. policy is clearly in favor of providing the injured party with the full range of remedies available to remedy his wrong unless he agrees otherwise. The disappointed expectations rule completely contradicts this U.C.C. policy. The disappointed expectations rule provides that in the event a defective product causes "other property" damage, the sole and exclusive remedy is through contract law, not tort law. The mandate is not triggered by the buyer expressly agreeing to such a limitation as required by the U.C.C., but rather by the failure of the buyer to have foreseen certain damages and have provided for them in the contract. No one could reasonably object to such a limitation where it is the subject of free bargaining as required by the U.C.C. But, to impose such an exclusive limitation in the absence of bargaining is contrary to the U.C.C.'s policy of bargaining for an exclusive remedy.

\section{CONCLUSION}

The disappointed expectations rule provides that when a defective product causes property damage that was reasonably foreseeable at the time of contracting, contract law is the sole remedy available to the buyer. The rule is

260. U.C.C. § 1-302; WIS. STAT. § 401.102(3).

261. U.C.C. § 1-302; WIS. STAT. § 401.102(3).

262. Ins. Co. of N. Am. v. Cease Elec. Inc., 688 N.W.2d 462, 468 (Wis. 2004).

263. U.C.C. § 2-711 (2003); WIS. STAT. § 402.711 (2007-2008).

264. U.C.C. $\S 2-719$ (2003); WIS. STAT. $\$ 402.719$ (2007-2008).

265. U.C.C. $\S 2-715(2)$ (b) (2003); WIS. STAT. § 402.715(2)(b) (2007-2008).

266. U.C.C. § 2-719(1)(a) (2003); WIS. STAT. § 402.719(1)(a) (2007-2008).

267. U.C.C. $\S 2-719(1)(b) ;$ WIS. STAT. $\$ 402.719(1)(b)$. 
the most recent progression of tort law drowning in a sea of contract law. The Wisconsin Supreme Court has recently adopted the rule. The rule, however, is deeply flawed. First, it provides a tort immunity to sellers/manufacturers without them bargaining for such protection. Tort immunity is normally a bargained-for protection. It should not be given by judicial fiat. Also, one must satisfy stringent bargaining requirements to gain tort immunity. Those bargaining requirements are rendered meaningless by the disappointed expectations rule. Second, the disappointed expectations rule essentially destroys the "other property" exception to the economic loss doctrine. "Other property" damage has always been the domain of tort law. The disappointed expectations rule converts reasonably foreseeable property damage into consequential damages governed by the U.C.C., not tort law. Third, the impact of the increasing contract coverage for defective products and corresponding decrease in tort coverage is to undercut the public policy of tort law that encourages manufacturers to produce safer products. Fourth, the disappointed expectations rule is, and has proven to be, an enigma for the courts to decipher and apply in a fair and uniform manner. Each one of these criticisms alone is reason enough to not support the disappointed expectations rule. Together, however, they overwhelmingly indicate the disappointed expectations rule is not a positive addition to the legal landscape of the economic loss doctrine. 